\title{
リンガル・バーの曲げ方
}

羽賀 通 夫* 清 水 忠

\section{The process of making a lingual bar by bending a wire.}

Michio Haga, Tadashi Shimizu.

局部床義歯を 構成するものの一つにバー（Bar）があ る.それは用いられる部位によつてパラタル・バー、リ ンガル・バー, バッカル・バー等々と呼ばれ形もそれぞ れ異つている.

バーの製作方法には鋳造法と，既製バー用線を各症例 に適合するように屈曲する方法, あるいは細線を二本平 行に置いて鑞着する方法等がある.しかし適合性からみ た場合，鋳造による方法がはるかに良く，また作り方か らいっても最も容易であると思う。

しかし現在のわが国の経済的面からは必ずしも全てを 鋳造法のみに頼ることができない現状では，それ以外の 方法も併用せざるを得ないというのが実状であろう。鋳 造以外の方法の中でも既製バー用線を屈曲して床の二部 の連絡をくわだてる場合が多い、けれどもこの方法は適 合が鋳造法に比して悪く且つ困難である.Co-Cr 合金の 既製バー用線では適合を良くするために屈曲の回数がた び重なつて来た場合には逆に加工硬化をおこしてくるた めにさらに屈曲の困難なものとなってしまう．

また一方バー用線は一方向に圧扁された形で製品とな つているために，屈曲によつて次第に三次元的な複雑な 形になつてくると，圧扁された薄い面内での屈曲が次第 に困難な立場に追、込まれてくる。それでもなおわれわ れは適合度を高めなければならない，そのような点でい つも困難を感じるのはリンガル・バーである. 前方パラタ ル・バーにおいては最早鋳造法に上る以外ほとんど不可 能といわざるを得ない，したがつてここでは単にリンガ ル・バーにのみ触れ, 且つ少しでも適合性の良いものを 作る上の参考ともなればと思い以下の一文をまとめた.

まずリンガル・バーの屈曲は二つの屈曲面にわけて考 えた方が便利である. 一つはバーの圧扁された面を含む

* Depart. of Prosthetic Dentistry, Tokyo Dental College. (Director: Prof. Katsue Kitamura) 東京歯科大学補経学教室（指導 北村勝徫）

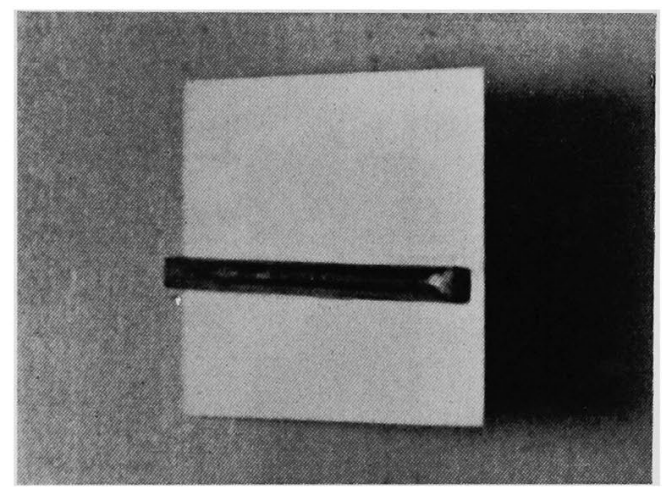

図 1

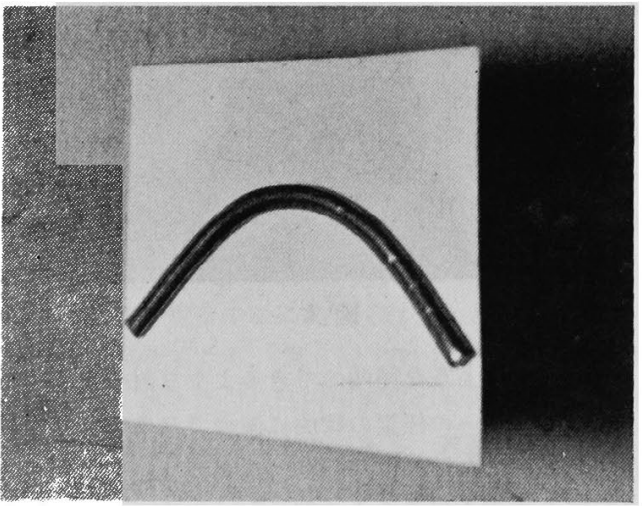

図 2 A 屈曲

薄い方の平面内での屈曲 (図 2) 他の一つは圧扁された幅 の広、面自体の屈曲 (図 3 ) とである (以下前者をA屈曲, 後者を $\mathrm{B}$ 屈曲と呼ぶ）鉗子を通常この二つの方向の屈曲 にそれぞれ適するように切れ込みを二つ以上持つていて (図 4) A 屈曲はA部で，B屈曲はB部が適するようにな つている.

ところが通常， B 屈曲が行われた後になると， A 屈 曲,すなわち薄い面に沿つた方の屈曲が困難になってく 


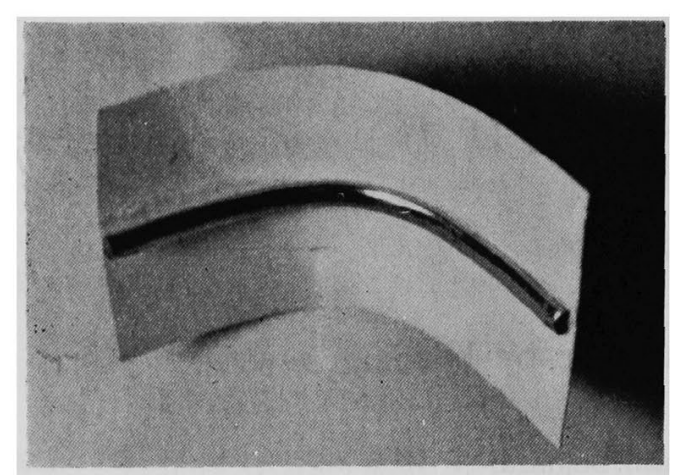

图 3 B 屈曲

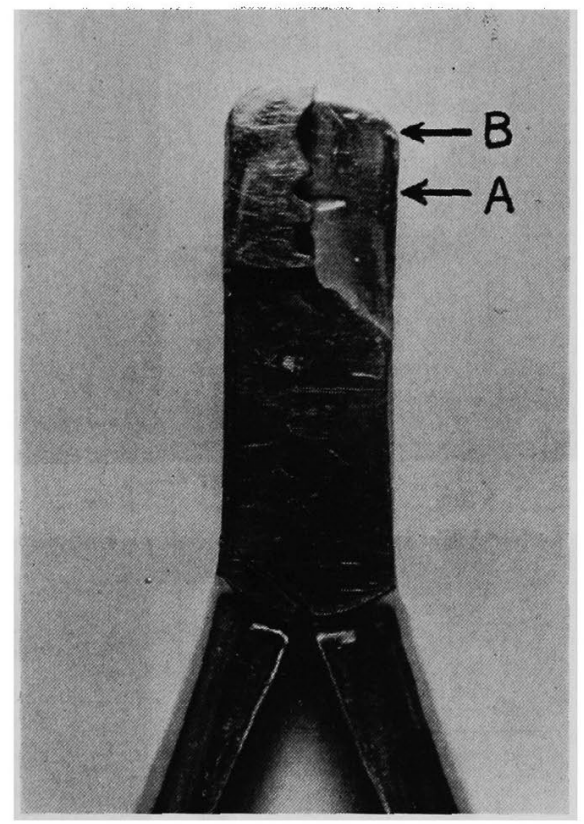

図 4

る、敢えてそのような屈曲のできるような鉗子をつくろ うとすれば，バーの任意の彎曲记適合できるような切れ 込みが考案されなければならないであ万う、したがつて どうしてもまずA屈曲を $\mathrm{A}$ の部(図 4)を使つて先に行わ なければならない，…第一段階 幅の広、面の屈曲は， 多少鉗子の切れ込みの適合が悪くても容易に屈曲するこ とができるので，その前に第一段階の屈曲をほとん完了 させておく必要がある。....第二段階

そこで問題を第一段階にしぼつて，これをいかに処理 するかについて以下触れたいと思う．前述のように第一 段階というのはA屈曲の操作のみを含むものである，従 来バーの屈曲を容易にするための工夫が行われているけ れども, シート・ワックスの圧接法もその一つである.
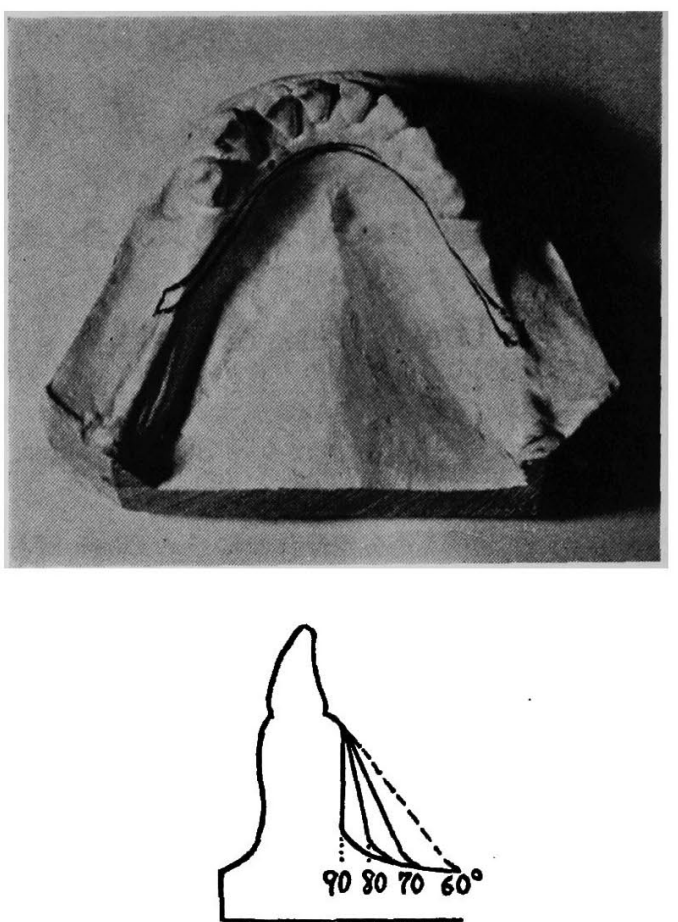

図 5

すなわちまず模型上にバーの設計を壘書する，次にその 上にシート・ワックス, またはパラフイン・ワックスを 圧接し，これを下に透かしてみえる設計線にしたがつて 切り取つてバーの形に残す. そしてこれを模型から取り はずして静かに平面上に展開させる、こうして平面上に 得られた形が，先に述べた $\mathrm{A}$ 屈曲に相当するものの全容 である.したがって,この形に沿つてバーをA屈曲し， 続いて B 屈曲を模型に試適しながら屈曲していくことに よって次第にバーの裹面の全面を模型の面に適合させて いくことができる.

ところでこの方法を全ての症例に適応していけば常に 比較的容易に屈曲を終ることができるのであるが最初の シート・ワクックスの展開で得られる $\mathrm{A}$ 屈曲のための繇 曲は, 実は下顥前歯部歯槽の舌面の傾斜の度合に左右さ れているのである.いいかえれば正中部において、バー の断面の圧扁された面が, バーの横走部に対してどの程 度傾斜しているかによつて屈曲の形が変わつてくる（第 5 図).

ここで一寸リンガル・バーの適応症について触れてお き度い，もともとバーは，局部床義歯の二つの部分の連 結と, 場合によつては間接維持の役目を果している.し かしここで述べているような既製バー用線をまげて作る 

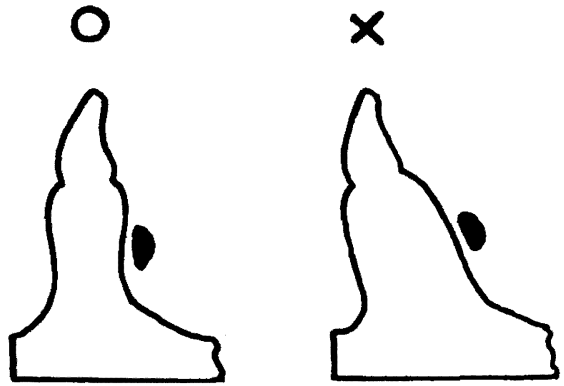

図 6

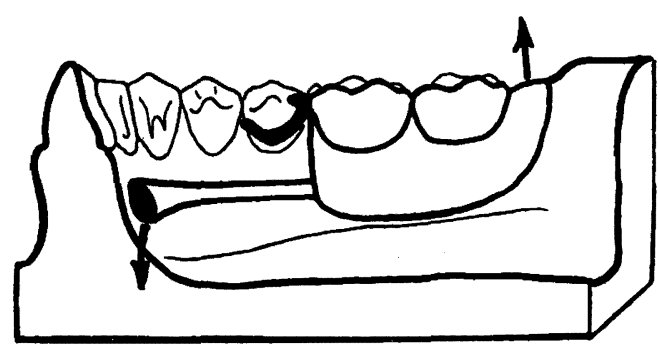

図 7

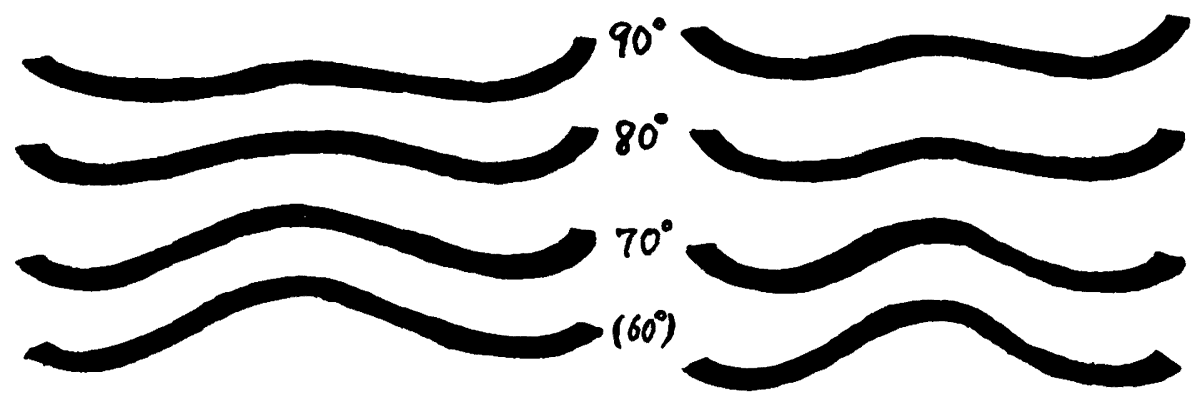

図 8

場合は主として連結のためのものである.リンガル・バ 一で舌側部を連結することによつて，レジン床の場合よ りも清潔且つ幅狭く強固な連結が得られる. また場合に よつては第 6 図のように舌側に添浻があつて，床を用い ては着脱不能のような時に好んでバーが使用される.

ところが下顥遊離端義齢のように, 後方の遊離端が浮 上すると, 第 7 図で明らかなように, バーの正中部が下 方に沈下する．あるいは臼歯部歯槽に吸収を起すと全体 に沈下して，バーは局部的に粘膜を刺激するようにな る.したがつてリンガル・バーは当初, 粘膜よりどの位 離して設置するかが問題である. 第 6 図のように舌側の 歯槽が垂直またはそれに近い場合には若干の沈下に対し て安全であるので両者の近接が可能である．またこの舌 側の傾斜がゆるやかな場合には，バーの僅かな沈下で粘 膜に達してしまうのでやや両者を離さねばならない、し たがつて傾斜のゆるやかなものは，バーに対しては不適 当といわざるを得ないが，その場合にはむしろ床として 沈下を防ぎ，間接維持の役目を果たさせた方がはるかに
有効である.

そこで私は正中部歯槽舌面の傾斜のゆるやかな方を約 70 度までとみて,垂直の場合から 10 度おきに, 90 度, 80 度，70 度，と参考のために 60 度の 4 段階にわけ同じ模 型を用いてシート・ワックスを圧接, 前記したようにバ 一の外形に沿つて切り取り平面に展開させてみた, その 結果舌側の傾斜角度の変化に応じて, A屈曲のための形 が次第に変化して行くのがわかる(第 8 図). すなわち, 歯槽が垂直である場合にはA屈曲はほとんど不必要であ るが，傾斜がゆるやかになつて行くとともにA屈曲の彎 曲が強くなつてくる．第 8 図 (右) はV字型歯穹のもの に対して，第 8 図(左)は円型歯穹のもので上記の舌面傾 斜毎に平面に展開したものである. 若し日常の臨床にお いて手早くバーをまげようとする場合に参考にされると 便利かもしれない。

以上稿を終るに臨み, 御指導御校閲戴いた北村勝衙教 授に深謝致します。 